

\title{
薬斉誘発性糖尿病ラットにおける 糖尿病発症早期の膀胱機能障害
}

\author{
五十嵐 匠 ${ }^{1)}$ 吉澤 剛1) 佐藤 克彦1) 平方 仁1) \\ 川田 望1) 高橋 悟1) 和田 義之 ${ }^{2)}$ 國分真一朗2) \\ ${ }^{1)}$ 日本大学医学部泌尿器科学系泌尿器科学分野 \\ ${ }^{2)}$ 日本大学医学部生体機能医学系生理学分野
}

\section{Impaired Voiding Function in Drug-induced Diabetic Rats in the Early Phase of the Disease}

Takumi IGARASHI ${ }^{1)}$, Tsuyoshi YoshizawA ${ }^{1)}$, Katsuhiko SATo ${ }^{1)}$, Hitoshi Hirakata ${ }^{1)}$, Nozomu Kawata ${ }^{1)}$, Satoru Takahashi ${ }^{1)}$, Yoshiyuki $\mathrm{WADA}^{2)}$ and Shinichiro KoKUBUN ${ }^{2)}$

${ }^{1)}$ Department of Urology, Division of Urology, Nihon University School of Medicine

${ }^{2)}$ Department of Biomedical Sciences, Division of Physiology, Nihon University School of Medicine

\begin{abstract}
We prepared three groups of female rats; streptozotocin-induced diabetic rats (STZ group), rats with physiological polyuria due to free ingestion of 5\% sucrose solution (PU group) and age-matched control rats (C group), and investigated the voiding dysfunction during the early phase of the diabetes mellitus, by comparing various parameters after 1 and 4 weeks of treatment. Parameters examined were total voided volume, tidal voided volume (TV), bladder capacity (BC), based pressure (BP), maximum voiding pressure (PP), bladder opening pressure (BOP) and postvoid residual volume (PVR). TV and BC at 1 and 4 weeks were increased significantly in the STZ and PU groups, compared with the C group, but there were no significant differences in either of these parameters between the STZ and PU groups. PP in the PU group increased significantly compared with that in the $\mathrm{C}$ group at both 1 and 4 weeks, although PP decreased significantly in the STZ group at 4 weeks, compared with the C group. BOP and PP of the STZ group at 1 week were decreased significantly compared with the PU group. A large PVR was only observed in the STZ group at 4 weeks, and BP was decreased significantly compared with both the control and PU groups. These results suggest that the function of the autonomic nerve system was impaired at $\sim 1$ week after the onset of diabetes mellitus, and that the inability to physiologically adapt to polyuria in the diabetic rats, due to the impaired autonomic function, induced voiding dysfunction during the early phase of the disease.
\end{abstract}

Key words: streptozotocin-induce diabetes, bladder dysfunction, polyuria, micturition function, bladder Streptozotocin 誘発糖尿病, 膀胱機能障害, 多尿, 排尿機能, 膀胱

(J. Nihon Univ. Med. Ass., 2012; 71 (5): 322-328)

要旨 ラットを streptozotocin 誘発糖尿病群 (STZ 群), $5 \%$ 蔗糖溶液飲用による生理的多尿群 (PU 群) に分けて各 群の 1 週目，4 週目における膀胱機能を測定しコント ロール群 (C 群) と比較検討することで糖尿病発症早期に おける排尿機能障害を検討した . STZ 群と PU 群は C 群 と比較して 1,4 週目とも 1 回排尿量と膀胱容量が有意 に増加したが, STZ 群と PU 群間では有意差はなかっ た . PU 群の排尿時最大収縮圧 (PP) は尿量の増加に伴い 1,4 週目とも C 群より有意に増加したが , STZ 群では 4 週目で逆に優位な低下を認めた . 排尿閾値圧と PP は PU 群と比較し STZ 群では 1 週目ですでに有意に低下し， 4 週目でSTZ 群のみ多量の残尿を認め, 基礎圧も PU 群 と比較して有意な低下を認めた .この結果は, 膀胱を支 配している自律神経の障害が糖尿病発症後 1 週間程度で
発生し，多尿に対する生理的適応ができず早期の排出障 害を引き起こすことを示唆した .

$$
\text { はじめに }
$$

糖尿病性神経障害による膀胱機能障害を有する患者 は, 糖尿病患者数の増加 (予備軍も含め 3480 万人 : 平成 21 年の厚生労働省調査結果) に伴(増加する傾向にある。 膀胱機能障害は糖尿病患者の 40-70\%に存在すると報告 されており1,2)，炎の症状は排尿困難，残尿感等の排出障 害や頻尿，尿意切迫，尿失禁などの蓄尿障害等多彩な症 状を呈する ${ }^{3)}$. 光の一方で自覚症状のない無症候性の患 者も多〈存在する ${ }^{1)}$.

糖尿病性膀胱機能障害で, 尿閉など，膀胱が過伸展す るような状態が生じた場合, 排尿筋の不可逆的変化を生 
じることがあるので，より早期に治療を開始することが 望ましい，つまり，膀胱機能に影響を与える糖尿病性神 経障害が, 糖尿病罹患後どのくらいの期間で発症するか を把握する事は, 治療の観点から非常に重要である.し かしながら, 発生時期や爫の成立過程, 病態生理学的な メカニズムには未だ不明瞭な点が多い．

糖尿病性神経障害による膀胱機能障害を解明するため に, streptozotocin (以下 STZ)により糖尿病を誘発した ラットを使用し，膀胱内圧測定等の膀胱機能の生理学的 検討, 膀胱および末梢神経の病理学的もしくは神経学的 検討, 薬斉投与による膀胱への影響の解析などが行われ ている ${ }^{418)}$. 膀胱機能の測定方法においては, 麻酔下で 行われているものから ${ }^{4,8 \sim 12,16)}$, 麻酔後カテーテル挿入 などの処置を行い覚醒させてから測定を行う方法 ${ }^{14,15) ，}$ 膀胱を取り出し in vitro で測定する方法など6, 13,17,18) か報 告されている . 麻酔下の膀胱内圧測定実験については， 使用した麻酔薬がシナプス伝導に影響を及ぼし, 膀胱の 収縮を抑制するという報告7)があり，麻酔の影響がなく より正確な膀胱内圧を測定するためには覚醒下での実験 か好ましい．また，STZ 投与後膀胱内圧測定を行なうま での期間は 2 週間から 6 ケ月とさまざまであるが，产の ほとんどは糖尿病誘発後 8〜12 週目以降に行われてお り, 光れ以前の誘発後早期に膀胱内圧を測定しているも のは報告数が少ない，膀胱機能の測定結果も測定時期や 測定方法により多岐にわたる .

糖尿病罹患後早期の膀胱機能は前述のごとく報告数が 少なく不明な点が多い，今回の実験では，糖尿病早期の 膀胱機能を評価し, 糖尿病特有の膀胱機能の变化が糖尿 病発症早期から認められるかどうか，また認められると すればどのように変化しているのかを検討するために実 験を行った。

\section{I. 実験方法}

\section{1. 実験動物}

実験には 7〜11 週齢の雌 Wistar ラット (体重 130〜210 g) を使用した .ラットはコントロール群 (C 群)，STZ を 投与した糖尿病群 (STZ 群)，水の代わりに $5 \%$ Sucrose 水溶液を飲用させ, 生理的に尿量か増加した多尿群 (PU 群)の 3 群に分けて飼育した .なお, 各群の実験前の体 重には特に有意差は認められていない .

2. 各群におけるラットの作成方法

· $\mathrm{C}$ 群

ラットの腹腔内へ STZ の溶解液である $0.05 \mathrm{M} の$ citrate buffer (pH 4.5) を, STZ を投与する場合同樣 $1 \mathrm{ml} / \mathrm{kg}$ 単回投与し，実験に使用する STZ 群と同週龄のラットを 使用した . 溶解液投与後 1 週目のラットを $\mathrm{C} 1 \mathrm{w}$ 群 $(\mathrm{n}=$ 5)，4 週目のラットを $\mathrm{C} 4 \mathrm{w}$ 群 $(\mathrm{n}=4)$ とした .

- STZ 群

ラットを 24 時間絶食後, STZ $0.05 \mathrm{M} の$ citrate buffer
(pH 4.5) に溶解し腹腔内に $60 \mathrm{mg} / \mathrm{kg}$ を単回投与した . 実験直前に血清グルコース值を測定し，血清グルコース 值が $250 \mathrm{mg} / \mathrm{d} l$ 以上を $\mathrm{STZ}$ 群として実験に使用した . STZ 投与後 1 週目のラットを STZ1w 群 $(\mathrm{n}=6), 4$ 週目 のラットを STZ4w 群 $(\mathrm{n}=5)$ とした .

・PU 群

ラットの飲用水として，5\% Sucrose 水溶液を水の代わ りに使用した . 水溶液は自由飲水とし尿量を増加させ た. $5 \%$ Sucrose 水溶液の飲用開始後 1 週目を PU1w 群 $(\mathrm{n}=5), 4$ 週目をPU4w群 $(\mathrm{n}=5)$ とした .

3. 膀胱内圧測定用カテーテルの留置方法

ラットの膀胱内圧をより生理的な状況で測定するため に，実験前に測定用カテーテルを以下の方法であらかじ めラットの体内へ留置した .

1) 直径 $0.965 \mathrm{~mm}$ のポリエチレンカテーテル (PE-50, Becton Dickinson Co. Ltd., USA) を $100 \mathrm{~cm} の$ 長さに切断 し, カテーテルの一方の先端を火であぶり丸くし，光の 丸くした先端より $2 \mathrm{~mm}$ の部分に $1 \mathrm{~mm}$ の大きさの側孔 を開けた . カテーテルはラットに留置する直前にカテー テル内を生理食塩水で満たした。

2) ラットをペントバルビタール $(30 \mathrm{mg} / \mathrm{kg})$ にて麻酔 後, 両耳の間の後頭部の皮膚を約 $0.5 \mathrm{~cm}$ 切開した . 光 の後ラットを仰臥位にして下腹部を約 $1 \mathrm{~cm}$ 縦切開し膀 胱を露出させた . 露出させた膀胱の頑部を $5 \mathrm{~mm}$ 切開し， 1)て作成したカテーテルの先端を丸くした側を膀胱内へ 挿入した . 挿入したカテーテルをタバコ縫合にて膀胱へ 固定した . カテーテル留置後, 生理食塩水をカテーテル より注入して , カテーテル挿入部から生食の漏れがない ことを確認し, カテーテルをラットの背部の皮下へ埋め 込み，下腹部と後頭部の創を閉創した .

4. 膀胱内圧の測定 (Fig. 1)

カテーテル留置 3 日後にエーテルにてラットを麻酔 し，背部の皮下に埋め込んだカテーテルを体外へ引き出 した .ラットを麻酔より覚醒させた 3 時間後, 高さ 20 $\mathrm{cm}$, 幅 $24 \mathrm{~cm}$, 奥行 $20 \mathrm{~cm}$ のケージに入れた . ケージ 外に固定した滑車に引き出したカテーテルを通した後, カテーテルの先端には 3 方活栓を接続し, 关の一方を圧 トランスデューサーに，他方を自動注入装置 (TE331， テルモ社) に接続し膀胱内圧の測定を行った . 自動注入 装置には生理食塩水の入ったシリンジをセットし，1.2 $\mathrm{m} l / \mathrm{h}$ の速度で生理食塩水の注入をおこなった．また， ケージの下には尿量を測定するための秤 $(\mathrm{GX}-200 ・ エ$ 一・アンド・デイ社)を置き, 1 回排尿量を同時に測定で きるようにした . 測定した各種膀胱内圧および 1 回排尿 量はコンピューターに出力した . 残尿量を測定するため に, 排尿直後カテーテルと 3 方活栓との接続をはずし， シリンジにてカテーテルより尿を用手的に吸引した . ま た，1回排尿量と残尿量の和を膀胱容量とした。 




Fig. 1 Cystometry

Three hours after regaining consciousness, the rat was placed in a specially designed cage. A balance (EK 120A, A\&D Co., Ltd.) was placed under the cage to simultaneously determine micturition volume. $0.9 \%$ saline solution was infused at a rate of $1.2 \mathrm{ml} / \mathrm{h}$. After a micturition had ceased, the infusion was stopped and the residual volume measured by aspiration from the catheter. The bladder pressure was recorded on computer.

Table 1 Body weight and blood glucose in STZ group, PU group and C group. Numbers show median \pm quartile deviation

\begin{tabular}{l|cccccc}
\hline & C1w group & C4w group & PU1w group & PU4w group & STZ1w group & STZ4w group \\
\hline Body weight $(\mathrm{g})$ & $150 \pm 7.5$ & $200 \pm 7.5$ & $165 \pm 2.8^{*}$ & $198 \pm 15.7$ & $150 \pm 0.0 \dagger$ & $160 \pm 16.2 * \dagger$ \\
Blood glucose $(\mathrm{mg} / \mathrm{dl})$ & $103 \pm 4.0$ & $102 \pm 3.0$ & $134 \pm 25.2 *$ & $133 \pm 18^{*}$ & $530 \pm 62^{*} \dagger$ & $600 \pm 102^{*} \dagger$ \\
\hline
\end{tabular}

*Significantly different from control group $\mathrm{p}<0.05$ $\dagger$ Significantly different from polyuria group $p<0.05$

Table 2 Micturition volume, residual volume and bladder capacity in STZ group, PU group and C group. Values are expressed in gram. Numbers show median \pm quartile deviation

\begin{tabular}{l|cccccc}
\hline & C1w group & C4w group & PU1w group & PU4w group & STZ1w group & STZ4w group \\
\hline Micturition volume (g) & $0.23 \pm 0.22$ & $0.16 \pm 0.10$ & $0.74 \pm 0.20^{*}$ & $0.38 \pm 0.32 *$ & $0.70 \pm 0.31 *$ & $0.68 \pm 0.33^{*}$ \\
Residual volume (g) & 0 & 0 & 0 & 0 & $0.003 \pm 0.003$ & $0.3 \pm 0.12^{*} \dagger$ \\
Bladder capaciyty (g) & $0.23 \pm 0.22$ & $0.16 \pm 0.10$ & $0.74 \pm 0.20^{*}$ & $0.38 \pm 0.32 *$ & $0.70 \pm 0.29 *$ & $0.95 \pm 0.29 *$ \\
\hline
\end{tabular}

*Significantly different from control group $\mathrm{p}<0.05$ $\dagger$ Significantly different from polyuria group $\mathrm{p}<0.05$

\section{5. 評価項目と 統計方法}

各群における体重, 血糖, 1 回排尿量, 残尿量, 膀胱 容量, 膀胱内圧 (基礎圧, 排尿閾値圧, 排尿時最大収縮 圧)ついて評価を行った .結果の統計学的有意差は MannWhitney のU 検定を用いて評価を行い，測定值は中央值 \pm 四分位偏差で表記し $\mathrm{P}<0.05$ を有意差ありと判定した .

\section{II. 結 果}

1. 体重, 血糖 (Table 1)

$\mathrm{C} 1 \mathrm{w}$ 群と比較して, 生理的に尿量を増加させた PU1w 群では有意に体重の増加 $(\mathrm{p}=0.009)$ と血糖の上昇 $(\mathrm{p}=$ 0.009) を認めた . また PU1w 群と STZ1w 群の比較では STZ1w 群で有意な体重の減少 $(\mathrm{p}=0.006)$ と血糖の増加 を認めた $(\mathrm{p}=0.006) . \mathrm{C} 4 \mathrm{w}$ 群と $\mathrm{PU} 4 \mathrm{w}$ 群の比較では PU4w 群で血糖の増加を認めた $(\mathrm{p}=0.01) . \mathrm{PU} 4 \mathrm{w}$ 群と
$\mathrm{STZ4w}$ 群の比較では STZ4w 群で有意な体重の減少 $(\mathrm{p}=$ $0.01)$ と血糖の増加を認めた $(p=0.009)$.

2. 膀胱内圧測定時の 1 回排尿量, 残尿量, 膀胱容量 (Table 2)

$\cdot 1$ 回排尿量

$\mathrm{C} 1 \mathrm{w}$ 群と比較して PU1w 群では有意に 1 回排尿量が 増加していた $(\mathrm{p}=0.02) . \mathrm{PU} 1 \mathrm{w}$ 群と STZ1w 群の比較で は有意差は認められなかった $(\mathrm{p}=0.58) . \mathrm{C} 4 \mathrm{w}$ と PU4w の比較では PU4wで1 回排尿量の有意な増加を認めた $(\mathrm{p}=0.01) . P U 4 \mathrm{w}$ と STZ4w の比較では有意差は認められ なかった $(\mathrm{p}=0.11)$.

\section{- 残尿量}

残尿量は C1w 群, C4w 群, PU1w 群, PU4w 群とも に認められなかった．また，STZ1w 群の残尿は $0.003 \pm$ $0.003 \mathrm{~g}$ であり，ほぼ残尿は認められなかった．しかしな 
Table 3 Cystometric variables in STZ group, PU group and C group. Values are expressed in $\mathrm{cmH}_{2} \mathrm{O}$. Numbers show median \pm quartile deviation

\begin{tabular}{l|cccccc}
\hline & C1w group & C4w group & PU1w group & PU4w group & STZ1w group & STZ4w group \\
\hline Based pressure $\left(\mathrm{cmH}_{2} \mathrm{O}\right)$ & $11.48 \pm 2.45$ & $14.0 \pm 2.0$ & $9.44 \pm 2.30$ & $9.57 \pm 4.50$ & $10.0 \pm 3.50$ & $7.2 \pm 1.50 * \dagger$ \\
Based opening pressure $\left(\mathrm{cmH}_{2} \mathrm{O}\right)$ & $11.14 \pm 3.09$ & $14.7 \pm 2.0$ & $14.9 \pm 1.40$ & $11.5 \pm 6.0$ & $10.59 \pm 3.90 * \dagger$ & $9.14 \pm 0.90 * \dagger$ \\
Maximum voiding pressure $\left(\mathrm{cmH}_{2} \mathrm{O}\right)$ & $27.32 \pm 5.06$ & $29.7 \pm 3.0$ & $43.8 \pm 8.0 *$ & $38.9 \pm 10.80 *$ & $27.8 \pm 10.80 \dagger$ & $23.5 \pm 8.70 * \dagger$ \\
\hline
\end{tabular}

*Significantly different from control group $\mathrm{p}<0.05$
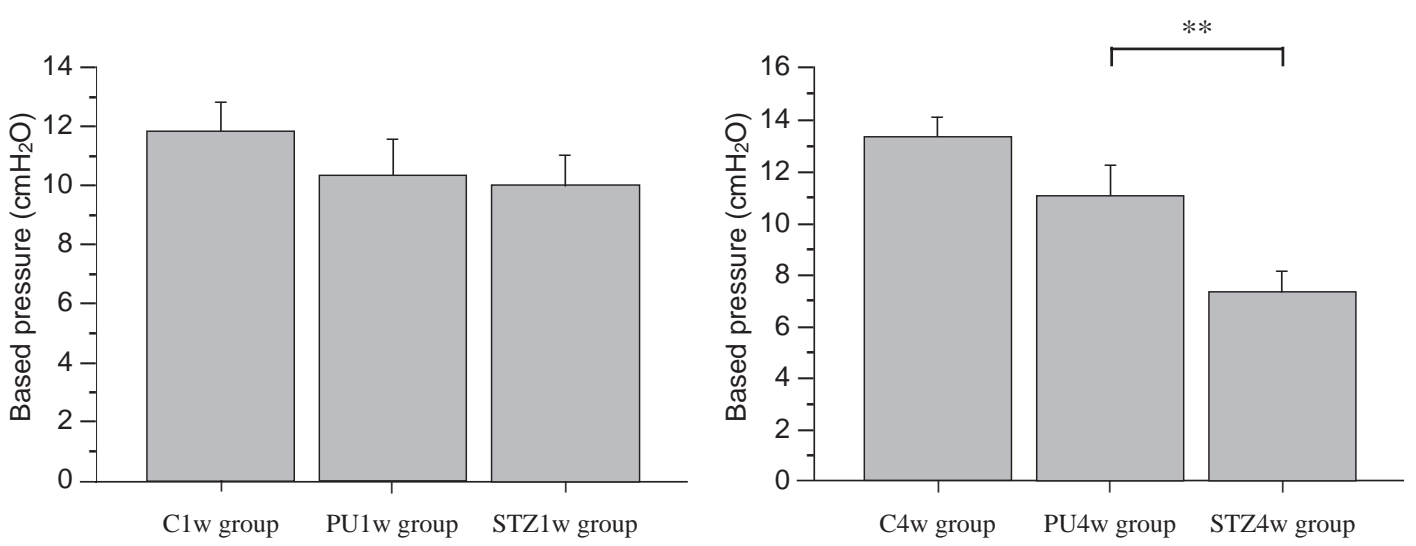

*Significantly different from control group $\mathrm{p}<0.05$

**Significantly different from polyuria group $\mathrm{p}<0.05$

Fig. 2 Based pressure (BP) data in STZ group, PU group and group at 1 and 4 weeks. Boxes and bars in each panel indicate median and quartile deviation, respectively.

がら，STZ4w 群では $0.3 \pm 0.12 \mathrm{~g}$ と多量の残尿を認めた．

- 膀胱容量

各 C 群と比較して各 PU 群で有意に膀胱容量の増加を 認めた $(1 \mathrm{w} ; \mathrm{p}=0.0283,4 \mathrm{w} ; \mathrm{p}=0.0143) . \mathrm{PU}$ 群と STZ 群 の比較では $1 \mathrm{w}$ 群 $(\mathrm{p}=0.58), 4 \mathrm{w}$ 群 $(\mathrm{p}=0.07)$ 共に有意 差は認められなかった .

3. 膀胱内圧測定 (Table 3)

- 基礎圧 (BP) (Fig. 2)

各 C 群と各 PU 群の基礎圧に有意差は認められなかっ た . PU1w 群と STZ1w 群の比較でも有意差は認められ なかった $(\mathrm{p}=0.71) . \mathrm{PU} 4 \mathrm{w}$ 群と比較して STZ4w 群で有 意に基礎圧の低下を認めた $(\mathrm{p}=0.02)$. また，弚の值は $\mathrm{C} 4 \mathrm{w}$ 群に対しても有意に低下していた $(\mathrm{p}=0.01)$.

・排尿閾値圧 (BOP) (Fig. 3)

各 C 群と各 PU 群では排尿域値圧に有意差は認められ なかった . PU1w 群と STZ1w 群の比較では STZ1w 群で 有意な低下を認めた $(\mathrm{p}=0.01) . \mathrm{PU} 4 \mathrm{w}$ 群と STZ4w 群の 比較でも STZ4w 群において有意差な低下を認めた $(\mathrm{p}=$ 0.04) .これらの各 STZ 群における低下は対応する C 群 に対しても有意差を認めた $(1 \mathrm{w}: \mathrm{p}=0.04,4 \mathrm{w}: \mathrm{p}=0.01)$.
・排尿時最大収縮圧 (PP) (Fig. 4)

PU 群と C 群との比較では谷れ光れの PU 群で有意に 排尿時最大収縮圧の上昇を認めた $(1 \mathrm{w}: \mathrm{p}=0.009,4 \mathrm{w}: \mathrm{p}=$ 0.01).STZ 群と PU 群の比較では, 各群ともに STZ 群 で有意な低下を認め $(1 \mathrm{w}: \mathrm{p}=0.01,4 \mathrm{w}: \mathrm{p}=0.009)$, かつ $\mathrm{STZ4w}$ 群では C4w 群に対しても有意な低下を認めた $(\mathrm{p}=0.04)$.

\section{III. 考察}

STZにより誘発された糖尿病ラットは膀胱機能障害の 実験モデルとしてよく使用されている . このモデルは STZ投与後 24 時間で高血糖となり糖尿病か誘発される. 糖尿病誘発後のラットは, 高浸透圧利尿・脱水・ケトア シドーシスを起こしている可能性がある．しかしなが ら, 末梢神経障害による膀胱機能障害にこれらのこと か関与している可能性は低く，今回の実験では特に検討 はしていない，ラットが糖尿病を誘発してから実験を行 うまでの期間は 2 週間から 6 ケ月までとさまざまな報 告4 18) があるが，今回われわれはいままで報告が少な かった STZ による糖尿病誘発後 1 週目および 4 週目の 

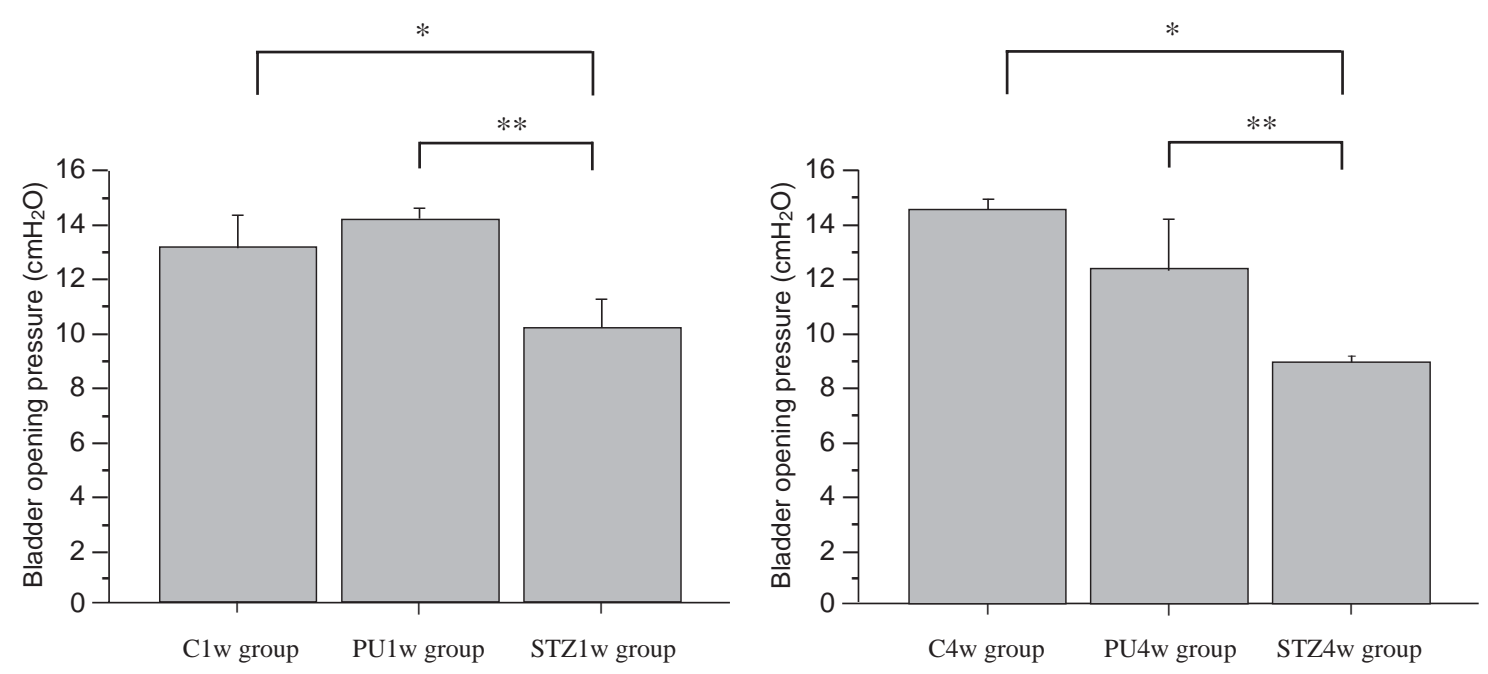

* Significantly different from control group $p<0.05$

**Significantly different from polyuria group $\mathrm{p}<0.05$

Fig. 3 Bladder opening pressure (BOP) in STZ group, PU group and C group at 1 and 4 weeks. Boxes and bars in each panel indicate median and quartile deviation, respectively.
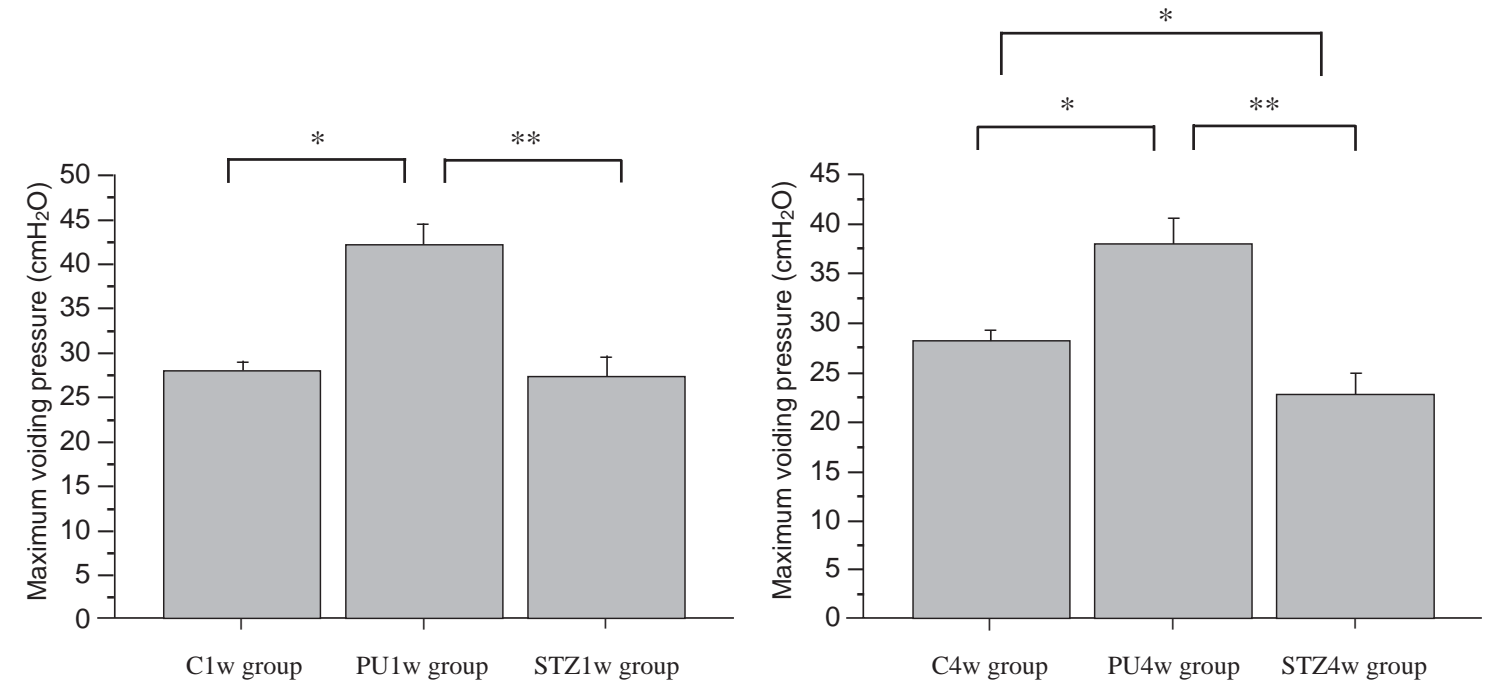

* Significantly different from control group $\mathrm{p}<0.05$

$* *$ Significantly different from polyuria group $\mathrm{p}<0.05$

Fig. 4 Maximum volding pressure (PP) in STZ group, PU group and C group at 1 and 4 weeks. Boxes and bars in each panel indicate median and quartile deviation, respectively.

\section{ラットの膀胱機能を検討した .}

今回の実験結果では, 糖尿病誘発後 1 週目のラットで はこれまでの報告4 18) と同樣に同週齢の C 群と比較し て高血糖と体重の減少を認めた。 $\mathrm{C} 1 \mathrm{w}$ 群と生理的に尿量 を増加させた PU1w 群の比較では, PU1w 群において 1 回排尿量の増加や膀胱容量の増加を認めた . 膀胱内圧測 定ではPU1w 群において排尿時最大収縮圧の有意な上昇 を認めた . 谷の一方, PU1w 群と STZ1w 群の比較では, 1 回排尿量や膀胱容量には有意差は認められなかった が, 膀胱内圧測定では有意な排尿閾値圧と排尿時最大収
縮圧の低下を認め, STZ 群ではすでに何かしらの膀胱機 能障害が疑われた．なお，この 1 週目の時点では各群と もに残尿は認めていない .

糖尿病誘発後 4 週目のラットでは, 1 週目と同樣に C 群と比較して高血糖と体重の減少を認めた。. C4w 群と生 理的多尿群である PU4w 群の比較では 1 週目と同樣に生 理的多尿群において 1 回排尿量と膀胱容量の増加，排尿 時最大収縮圧の上昇を認めた . PU4w 群と STZ4w 群の 比較では 1 回排尿量や膀胱容量に有意差はないものの $\mathrm{STZ} 4 \mathrm{w}$ 群において多量の残尿を認めた . 特に STZ4w 群 
では，基礎圧，排尿閾値圧，排尿時最大収縮圧のす心゙て が $\mathrm{C} 4 \mathrm{w}$ 群に対しても有意に低下しており，明らかな排 尿障害の存在を示唆した 。

ラットの糖尿病性膀胱機能障害の成因については, 膀 胱ムスカリンレセプターの変化が生じているためと報告 しているものや4, 12) 膀胱への自律神経の伝導速度の低下 から自律神経障害が原因としているもの ${ }^{5)}$ ， これとは 逆に膀胱機能障害は神経障害ではなく膀胱平滑筋や含 有コラーゲン量などの膀胱自体の変化によるとするも の ${ }^{15,18)}$, 早期では膀胱機能障害自体か認められないとす るもの ${ }^{17)}$ など一致した見解が得られていない . 佐藤ら ${ }^{19)}$ はSTZにより誘発された糖尿病ラットにおける膀胱 NGF 濃度の測定を行っている . 彼らの報告では, 糖尿病ラッ 卜の膀胱 NGF 濃度は 1 週目で急激に増加し, 光の後速 やかに低下するが高値を持続する．一方で，比較対象と しているシュークロースを飲用させた多尿ラットでも同 樣にNGF の上昇を認めるが, 弚の上昇の程度は緩徐で ある. 糖尿病ラット，多尿ラットは共に 1 日尿量が糖尿 病誘発後およびシュークロース飲用後急激に増加する が,多尿群の場合の NGF 上昇は,多尿に対する生理的な 対応として急激な膀胱平滑筋の伸展や, 膀胱重量の増加 に伴って上昇している，一方，糖尿病群では多尿に対す る生理的な対応としてのNGF上昇もあるが, 膀胱 NGF 濃度が生理的範囲を超えた上昇を示すことより，別の機 序も NGF 上昇に関与していると考えられるとしている．

膀胱は蓄尿と排尿を行う藏器であり，蓄尿時には膀胱 内圧は一定に保たれている .これは膀胱平滑筋や膀胱の 支配神経の働きによるもので，膀胱内圧測定では基礎圧 の部分にあたる . 尿量が最大尿意に達すると排尿筋の収 縮がおこり膀胱内圧が上昇する.この排尿開始前の膀胱 内圧か排尿閾值圧であり, 膀胱の知覚神経により尿の貯 留が感知され，排尿の反射が起こり排尿に至る.

今回の実験では，1 週目において生理的に多尿となっ たPU1w 群では排尿時最大収縮圧の上昇を認めた .この 変化は, 増加した多量の尿を膀胱より排出するための反 応であると推察される. 光の一方で, STZ1w 群では生理 的多尿群と同樣に尿量が増加しているにもかかわらず PU1w 群より優位に低値であった . このことは糖尿病誘 発後 1 週目の時点ですでに膀胱の運動神経障害が生じ ているものと推測される . かつ, STZ1w 群で排尿閾値圧 は $\mathrm{c} 1 \mathrm{w}$ 群に対しても低下を認め, 知覚神経の障害も同時 に発生していると推測される。これは糖尿病による膀 胱機能障害が自律神経に起因していると報告している Nadelhaft $ら^{5)}$ の報告や佐藤らが報告した糖尿病誘発後 1 週目に膀胱の NGF 濃度の上昇は自律神経の修復のため に上昇していると考えれば，今回の結果はこれらの報 告を支持するものである．また，糖尿病誘発後 4 週後の $\mathrm{STZ} 4 \mathrm{w}$ 群では多量の残尿，基礎圧，排尿閾値圧，排尿時 最大収縮圧の低下か顕著となり膀胱機能障害がさらに進
行した状態となっている．

人間における糖尿病性膀胱機能障害は, 自律神経の知 覚障害により膀胱知覚障害をきたし,さらに運動遠心路 の障害により排尿筋の収縮力が低下する .このことによ り膀胱容量の増大や残尿が生じる . 臨床上経験する糖尿 病性膀胱機能障害は低活動膀胱のことが多く，今回の ラットによる実験でも人間と同樣に低活動膀胱を認め た . また ,この膀胱機能障害は実験結果よりかなり早期 より発症している事が示唆され, 人間と同樣にラットの 糖尿病性膀胱機能障害も知覚, 運動障害が同時に発症し ているものと推測された .

\section{結語}

糖尿病誘発後 1 週目という非常に早期のラットに対し て膀胱内圧測定を行ない, 同時期より膀胱機能障害を認 めた . 臨床で経験する糖尿病性膀胱機能障害は, 糖尿病 が進行しており，膀胱機能障害も重度で治療に苦慮する ことが多い . 糖尿病発症後, 自覚症状のない時期に膀胱 機能障害を診断し，光れに対応した治療が行えればこの 問題は解決されるはずである．今回の実験では早期の膀 胱内圧測定で膀胱の機能に異常を認めており，糖尿病発 症早期の無自覚な糖尿病患者の膀胱機能障害の診断に は, 膀胱内圧測定が有用であることが示唆された .

\section{文献}

1) 服部孝道，安田耕作，北 耕平，他 . 糖尿病における排 尿障害一自覚症状のない症例における検討一.自律神経， 1988; 25: 418-421.

2) 姫井 孟, 内田耕三郎, 大橋輝久, 他 . 糖尿病性神経因 性膀胱の排尿動態検査指標について . 自律神経，1992; 29: 370-374.

3) 服部孝道, 安田耕作, 北 耕平, 他 . 糖尿病における排 尿障害 自覚症状を有するものにおける検討 . 自律神 経，1987; 24: 566-570

4) 北島正一。実験的糖尿病ラットの下部尿路機能に関する 研究. 日泌尿会誌, 1996; 87: 12-26.

5) Nadelhaft I, Vera PL. Reduced urinary bladder afferent conduction velocities in streptozotocin diabetic rats. Neuroscience Letters 1992; 135: 276-278.

6) Eika B, Levin RM, Longhurst PA. Comparison of Urinary Bladder Functionin rats with Hereditary Diabetes Insipidus Streptozotocin-induced Diabetes Millitus, and nondiabetic osmotic diuresis. J Urol 1994; 151: 496-502.

7) Yaksh TL, Durant PAC, Brent CR. Micturion in rats :a chronic model for study of bladder function and effect of anesthetics. Am J Physiol 1986; 251: R1177-1185.

8) Kudlacz EM, Chun KA, Saku KA, et al. Diabetes and Diureticinduced Alterations in Function of Rat Urinary Bladder. Diabetes 1988; 37: 949-955.

9) Steers WD, Mackway AM, Ciambotti J, et al. Effect of Streptozotocin-induced Diabetes on Bladder Function in the Rat. J Urol 1990; 143: 1032-1036.

10) Daneshgari F, Liu G, Imrey PB. Time Dependent Changes in Diabetic Cystopathy indlude Compensated and Decompensated bladder Function. J Urol 2006; 176: 380-386.

11) Wang CC, Nagatomi J, Toosi KK, et al. Diabetes induced Alter- 
ations in the Biomechanical properties of the Urinary Bladder Wall in Rats. Urology 2009; 73: 911-915.

12) Malmdren A, Andersson PO, Uvelius B. Bladder Function in rats with short-and long-term diabetes; effects of age and muscarinic blockade. J Urol 1989; 142: 1608-1614.

13) Longhurst PA, Belis JA. Abnomalities of rat bladder contractility in streptozotocin-ibduced diabetes mellitus. $J$ Pharmacol 1986; 238: 773-777.

14) Curley RM, Wagner CH, Murty VN, et al. Comparison of Computerized Cystometry micturition and Contractile Responses of the diabetic Rat Bladder. Pharmacology 1994; 49: 61-68.

15) Andersson PO, Malmgren A, Uvelius B. Cystometrical and in vitro evaluation of urinarybladder function in rats with streptozotocin-induce diabetes. J Urol 1988; 139: 1359-1362.
16) Santicioli P, Gamse R, Maggi CA, et al. Cystometric changes in the early phase of streptozotocin-induced diabetes in rat: evidence for sensory changes not correlated todiabetic neuropathy. Naunyu-Schmiedebergs Arch Pharmacol 1987; 335: 580587.

17) Moss HE, Lincoln J, Burnstock G. A Study of bladder dysfunction during streptozotocin-induced diabetis in the rat using in vitro whole bladder preparation. J Urol 1987; 138: 1279-1284.

18) Pitre DA, Ma T, Wallace LJ. Time-dependent urinary bladder remodeling in the streptozotocin-induced diabetic rat model. Acta Diabetol 2002; 39: 23-27.

19)佐藤克彦, 和田義之, 風間宏美, 他 . 薬剂誘発性糖尿病 多尿と生理的多尿での排尿機能再構築における膀胱組織 内神経成長因子の役割.日大医誌，2002; 61: 447-455. 